\title{
Managerial competencies: an analysis of classifications in empirical studies
}

Pablo fernando Pessoa de freitas

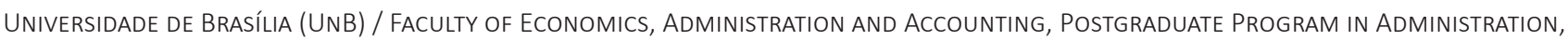
BRASÍLIA - DF, BRAZIL

Catarina Cecília Odelius

Universidade de Brasília (UnB) / FACUlty of ECONOMICS, AdMinistration ANd ACCOUNting, Postgraduate Program in AdMinistration,

BRASÍLIA - DF, BRAZIL

\begin{abstract}
This study presents a literature review on managerial competencies (MC) in order to identify the most mentioned classifications of $\mathrm{MC}$ in empirical studies (including schemes, models, categorizations, or even the mere identification of $\mathrm{MC}$ in a particular locus of research) from 2005 to 2015. Using bibliographic research and content analysis with a posteriori classification, 46 articles were investigated, along with their common and seminal references. It was concluded that the Quinn model was the most recurrent during the period studied as it appeared in 12 studies. Regarding the other 34 articles, the MC categories with a higher incidence were: result oriented (clients, processes, costs, market, products, projects, etc.); ability to work with people and teams (interpersonal relationship, cooperation, etc.); leadership, coordination, and motivation; ability to work in changing environments (innovation and situational adaptability capability); communication; planning; knowledge management; organization and control (resource allocation, mobilization, and monitoring); Attitudes and Values (ethics, initiative, commitment, etc.); and knowledge and technical skills in the field. Inquiries and criticisms were presented for the last two categories. Among several research recommendations, studies should identify the most relevant MC, even generic or transversal ones, in order to facilitate or allow the diagnosis of MC, providing further studies to concentrate on mapping specific competencies of the studied locus of research, as well as the replication of the study to verify the dynamic behavior of MC over time.
\end{abstract}

Keywords: Competencies. Managerial competencies. Classification of managerial competencies. Managerial competency models.

\section{Competências gerenciais: uma análise de classificações em estudos empíricos}

\begin{abstract}
Resumo
Este trabalho apresenta uma revisão de literatura sobre competências gerenciais (MC), visando identificar as classificações de $\mathrm{MC}$ mais citadas em estudos empíricos (contendo esquemas, modelos, categorizações ou ainda a mera identificação de MC em determinado locus de pesquisa) entre 2005 e 2015. Por meio de pesquisa bibliográfica e análise de conteúdo com categorização a posteriori, foram investigados 46 artigos, além de suas referências comuns e seminais. Como resultado, pôde-se concluir que o Modelo de Quinn (1988) foi o mais recorrente no período, estando presente em 12 estudos, e que, quanto aos 34 demais artigos, as categorias de MC com maior incidência foram: Orientação para resultados (clientes, processos, custos, mercado, produtos, projetos etc.); Habilidade com pessoas e equipes (relacionamento interpessoal, cooperação etc.); Liderança, Coordenação e Motivação; Habilidade com Mudanças (inovações e capacidade de Adaptação situacional); Comunicação; Planejamento; Gestão do Conhecimento; Organização e Controle (alocação e mobilização de recursos e monitoramento); Atitudes e Valores (Ética, iniciativa, comprometimento etc.); e Conhecimentos e Habilidades Técnicas da área), sendo que para essas duas últimas categorias foram apresentados questionamentos e críticas. Entre várias recomendações de pesquisa, sugerem-se estudos que identifiquem as MC de maior relevo, ainda que genéricas ou transversais, de modo a nortear ou facilitar a viabilização de diagnósticos de MC, proporcionando que os futuros estudos se concentrem em mapear competências específicas e peculiares do locus de pesquisa estudado; bem como a replicação do estudo, com o fito de verificar o comportamento dinâmico das MC ao longo dos anos.
\end{abstract}

Palavras-chave: Competências. Competências Gerenciais. Classificação de competências Gerenciais. Modelos de Competências Gerenciais.

\section{Competencias de gestión: un análisis de clasificaciones en estudios empíricos}

\section{Resumen}

Este trabajo presenta una revisión de la literatura sobre competencias de gestión (MC), con la intención de identificar las clasificaciones de MC más citadas en estudios empíricos (con esquemas, modelos, categorizaciones o incluso la mera identificación de MC en determinado locus de investigación) entre 2005 y 2015. A través de investigación bibliográfica y análisis de contenido con categorización a posteriori, se investigaron 46 artículos, además de sus referencias comunes y seminales. Como resultado, se puede concluir que el modelo de Quinn (1988) fue el más recurrente durante el período, presente en 12 estudios, y que, a respecto de los otros 34 artículos, las categorías de MC con mayor incidencia fueron: Orientación para resultados (clientes, procesos, costos, mercado, productos, proyectos, etc.); Habilidad con personas y equipos (relación interpersonal, cooperación, etc.); Liderazgo, Coordinación y motivación; Habilidad con cambios (innovaciones y capacidad de adaptación situacional); Comunicación; Planificación; Gestión del conocimiento; Organización y control (asignación y movilización de recursos y monitoreo); Actitudes y valores (ética, iniciativa, compromiso, etc.); y Conocimientos y habilidades técnicas del área-para esas dos últimas categorías se presentaron cuestionamientos y críticas-. Entre numerosas recomendaciones de investigación, se sugieren estudios que identifiquen las MC más relevantes, aunque sean genéricas o transversales, para poder orientar o facilitar la viabilidad de diagnósticos de MC, que posibiliten que los futuros estudios se concentren en mapear competencias específicas y peculiares del locus de investigación estudiado; así como la replicación del estudio, a los efectos de verificar el comportamiento dinámico de las MC con el paso del tiempo.

Palabras clave: Competencias. Competencias de gestión. Clasificación de competencias de gestión. Modelos de competencias de gestión. 


\section{INTRODUCTION}

The globalisation of economy defies and imposes adjustments on organisations so that they can follow the celerity of changes. Under this perspective, the business world engages in identifying and developing competencies required for business management (MORAES and CORRÊA, 2008). It is no different within the public sector: management competencies are at the epicentre of institutional tensions, whether regarding relations between politics and bureaucracy, flexibility and control requirements, or concerns about the impasse between citizens' needs and the limitation of available resources (TEIXEIRA, SILVA and LIMA, 2011).

In this context, the managerial competencies (MC) subject is becoming increasingly disseminated in the organisational context and has been gaining academic relevance, especially for its connection with phenomena such as learning, performance, and strategy of (in) organisations. Competent managers are those who (a) constantly learn and provide learning environments (ANTONELLO, 2005; FÉLIX, 2005; SANTOS, CAETANO and JESUÍNO, 2008; ZAGORŠEK, DIMOVSKI and ŠKERLAVAJ, 2009; LEITE, 2009); (b) conduct their teams and the organisations where they work to a higher level of performance (SANTOS, CAETANO and JESUÍNO, 2008; MORAES and CORRÊA, 2008; BRANDÃO, BORGES-ANDRADE and GUIMARÃES, 2012); and (c) seek strategic alignment in order to reach the institutional vision (MOURA and BITENCOURT, 2006; CARDOSO, 2009).

Given the relevance of MC for organisations, this essay aims to identify the most mentioned classifications of MC in empirical studies (containing schemes, models, categorisations, or even the mere identification of MC within a given locus of research) from 2005 to 2015. As a social justification, it is believed that a theoretical study that consolidates the recent literature regarding $\mathrm{MC}$ may help organisations, starting from the understanding of the most incidental $\mathrm{MC}$ in empirical studies, to identify their basic MC and guide competency mapping as well as the structuring of managerial development programs and the definition of other people-management policies.

Furthermore, as an academic justification, the scope of this work expects to contribute, even if indirectly, to (a) the composition of a study covering competencies and aspects related to management (strategic vision, systemic vision, people and resources management; ODELIUS, ABBAD, RESENDE JÚNIOR et al., 2011); (b) the analysis of how competencies may intermediate delivery relationships at work (BRANDÃO and BORGES-ANDRADE, 2008); (c) the identification of relevant competencies within several professional segments, purposes, and organisational contexts (GUIMARÃES, BORGES-ANDRADE, MIRAMAR et al., 2001; BÜNDCHEN, ROSSETTO and SILVA, 2011); and (d) the review of undergraduate business course curricula, which, according to Sousa and Valadão Júnior (2013) and Galvão, Silva and Silva (2012), would be outdated and insufficient concerning the development of people, leadership, and team management.

Thus, considering the aforementioned context, justifications, and objective, the data analysis and managerial competencies identified are presented below. Besides this introductory section, this article is composed of five other sections: competencies, the relationship between organisational theories and $M C$, method, MC, models and classifications, final considerations, and references.

\section{COMPETENCIES}

The expression 'competence' has been used under an eminently legal concept to denote task, responsibility for judgement, or issuing opinions since the Middle Ages. Only in the 1970s did the concept migrate to organisational psychology, notably in the seminal works of Gilbert and McClelland, who dedicated themselves to study individual competencies in the work context. Twenty years later, the phenomenon began to become more important in the administration field, becoming part of organisational studies in the 1990s (BRANDÃO, 2007; MONTEZANO, SILVA and COELHO JÚNIOR, 2015).

The study of competencies passes through multiple approaches. In addition, there is no conceptual and epistemological consensus regarding the subject. These are factors that worsen the challenge of evaluating or measuring competencies (GARAVAN and MCGUIRE, 2001; BRANDÃO and BORGES-ANDRADE, 2008). In this manner, the difficulty in measuring competencies tends to 
increase since an increasingly higher level of complexity is required in competencies, regardless of the field of work (GODOY and ANTONELLO, 2009).

Complex and multifaceted are proper adjectives for the competence concept (BRANDÃO, 2007). They sometimes refer to competencies as a result (what is done) and sometimes as a process (how it is done) (ROWE, 1995; BERGENHENEGOUWEN, HORN and MOOIJMAN, 1997).

However, the conceptual multiplicity is even greater. Brito, Paiva, and Leone (2012), using theoretical studies, presented this plurality when defining competencies, relating keywords, conceptual synthesis, and its main authors as seen in Box 1.

\section{Box 1}

\section{Conceptual synthesis about competencies}

\begin{tabular}{|c|c|c|}
\hline Keyword & Conceptual Synthesis & Main Authors \\
\hline Education & $\begin{array}{l}\text { Development of concept, skills, } \\
\text { and attitudes }\end{array}$ & $\begin{array}{l}\text { Boyatzis (1982), Parry (1996), Boog (1991), Becker (2001), Spencer and } \\
\text { Spencer (1993), Magalhães et al. (1997), Hipólito (2000), Dutra et al. } \\
\text { (1998), Sandberg (1996) }\end{array}$ \\
\hline Training & Aptitude (potential) & $\begin{array}{l}\text { Moscovicci (1994), Magalhães et al. (1997), Dutra et al. (1998), Zarifian } \\
\text { (2001) }\end{array}$ \\
\hline Action & $\begin{array}{l}\text { Working practices, ability to } \\
\text { mobilise resources, which } \\
\text { makes it different from the } \\
\text { concept of potential }\end{array}$ & $\begin{array}{l}\text { Sparrow and Bognanno (1994), Durand (1998), Hase et al. (1998), Cravino } \\
\text { (2000), Ruas (1999), Moscovicci (1994), Boterf (1997), Perrenoud (1998), } \\
\text { Fleury and Fleury (2000), Davis (2000), Zarifian (2001) }\end{array}$ \\
\hline Articulation & Resource mobilisation & Boterf (1997) \\
\hline Results & Search for better performance & $\begin{array}{l}\text { Boyatzis (1982), Sparrow and Bognanno (1994), Parry (1996), Hase et al. } \\
\text { (1998), Becker et al. (2001), Spencer and Spencer (1993), Cravino (2000), } \\
\text { Ruas (1999), Fleury and Fleury (2000), Hipólito (2000), Dutra et al. (1998), } \\
\text { Davis (2000), Zarifian (2001) }\end{array}$ \\
\hline Dynamic perspective & Constant questioning & Hipólito (2000) \\
\hline Self-development & $\begin{array}{l}\text { Individual learning process in } \\
\text { which the responsibility of the } \\
\text { process should be given to the } \\
\text { individual }\end{array}$ & Bruce (1996) \\
\hline Interaction & Relationship with other people & Sandberg (1996) \\
\hline
\end{tabular}

Source: Adapted from Brito, Paiva, and Leone (2012).

This conceptual multiplicity comes from seminal literature and was evidenced, for example, by Dutra (2004), Brandão (2007) and Carbone, Brandão and Leite (2009), as seen in Box 2. 


\section{Box 2}

Perspectives about competencies

\begin{tabular}{|c|c|c|}
\hline Perspective & Concept of competencies & Precursors \\
\hline $\begin{array}{l}\text { American (emphasis } \\
\text { on personal attributes) }\end{array}$ & $\begin{array}{l}\text { Set of qualifications or characteristics } \\
\text { underlying the person and that } \\
\text { occasionally allows the individual to } \\
\text { accomplish a given task and achieve } \\
\text { a higher performance or deal with a } \\
\text { given situation. }\end{array}$ & McClelland (1973) and Boyatzis (1982) \\
\hline $\begin{array}{l}\text { French (emphasis on } \\
\text { delivered performance } \\
\text { and context) }\end{array}$ & $\begin{array}{l}\text { Set of achievements produced by an } \\
\text { individual in a given work context and } \\
\text { not the set of attributes of a person. }\end{array}$ & Zarifian (1999) and Le Boterf (1999) \\
\hline $\begin{array}{l}\text { Integrated (emphasis } \\
\text { on personal } \\
\text { attributes, delivered } \\
\text { performance, and } \\
\text { context) }\end{array}$ & $\begin{array}{l}\text { Set of knowledge, skills, and } \\
\text { attitudes necessary to exercise a } \\
\text { given activity, but also the person's } \\
\text { performance in a given context in } \\
\text { terms of behaviours used at work and } \\
\text { following achievements. }\end{array}$ & Gonczi (1999) \\
\hline
\end{tabular}

Source: Elaborated by the authors based on the literature.

Some recent definitions corroborate with the American school: for example, the definitions made by Parry (1996), to whom competence is a set of knowledge, skills, and attitudes (constitutive elements of competence) that relate to one another and affect the majority of a task, role, or responsibility; and by Lima (2005), who thinks about competencies as personal characteristics (qualities) associated with the ability or attributes (cognitive, psychomotor, and affective) to solve certain issues, and when combined, create different ways to successfully achieve the essential and characteristic actions of a given professional practice.

More connected to the French school are the ideas of Fleury and Fleury (2001) that comprise competence as a responsible and acknowledged action that mobilises, integrates, and transfers knowledge, resources, and skills, adding economic value to the organisation and social value to the individual; and of Stuart and Lindsay (1997), who define competence as a value statement associated to a particular culture and within a given environment.

With regard to the integrative perspective, it is worth highlighting that even before Gonczi's definition (1999), considered pioneering, other authors were already simultaneously using elements from both American and French perspectives. Rowe (1995), for instance, indicated the definition of competence as skills related to an achieved performance standard or as behaviours by which it is possible to achieve a performance. Subsequently, other authors made progress on the definition of competencies, such as McMullan, Endacott, Gray et al. (2003), who sometimes understand competencies in a general way as inherent to the individual and linked to a higher level of performance, whether when fulfilling specific tasks or in a given context (getting closer to the American school); they also sometimes relate them to actions or behaviours or results that a person should demonstrate with the performance (approaching the French school).

Either way, it is already worth mentioning that the definition that agrees the most with this work is the one adopted by the integrated school. It is believed that it is not enough for leaders to hold a set of attributes if they are not used, so that the team or organisation raises their performance standard required by the context.

Lastly, it is noteworthy that many authors consider that the field of competencies coexist with a fragmented theory (BRANDÃO and BORGES-ANDRADE, 2008; GODOY and ANTONELLO, 2009); and that the majority of studies are limited to separately obtain the constitutive elements of competence (knowledge, skills, and attitudes) instead of the synergy between them (BRANDÃO, 2007). 


\section{THE RELATIONSHIP BETWEEN MANAGERIAL COMPETENCIES AND ORGANISATIONAL THEORIES}

The label 'managerial competencies' appeared for the first time in 1982 from the works of Richard Boyatzis. His book, The Competent Manager: A Model for Effective Performance, presented 21 competencies (organised into six dimensions) that should compose the ideal manager profile: efficiency orientation; proactivity; diagnostic use of concepts; concern with impact (Goal and Action Management Cluster); self-confidence; oral presentations; logical thought; conceptualisation (Leadership Cluster); use of socialised power; optimism; managing group process; self-assessment and critical sense (Human Resources Cluster); developing others; use of unilateral power; spontaneity (Directing Subordinates Cluster); self-control; perceptual objectivity; adaptability; concern with close relationships (Focus on Others Cluster); memory; and specialised knowledge (Specialized Knowledge Cluster) (BRITO, PAIVA and LEONE, 2012).

Boyatzis based his work on the behaviourist assumption that competencies are 'observable behaviours' that lead organisations to better performance and results, which would justify the importance of managerial training (PELISSARI, GONZALEZ and VANELLE, 2011; BRITO, PAIVA and LEONE, 2012). Godoy and D'Amelio (2012) believe that MC is different from competencies of other members in the same organisation, since the manager needs to focus on the expected results of his department using influence and leadership. Thus, new competencies are needed with greater responsibilities and that emphasise interpersonal relationships.

This study considers the definition of competencies according to the integrative approach, that is, $\mathrm{MC}$ is a set of observable or potential behaviours by which managers, as individuals, may demonstrate knowledge, skills, and attitudes or the synergy between them as personal attributes, adding value and better results for themselves, other individuals, and the teams, departments, organisations, or networks that are consistent with the context, the available resources, and the adopted strategy.

However, it is worth highlighting that the definitions of $\mathrm{MC}$ assumed nowadays have been influenced by several studies and theories, because managerial issues follow the general administration theory since its earliest beginnings. Even before MC was considered a specific phenomenon, several authors were already dealing with managerial aspects, serving as a basis for current studies. Some examples are the studies by Chester Barnard regarding the functions of the executive in 1938; the contribution of Herbert Simon about the decision-making process linked to the manager's performance in 1960; the description of the managerial role from the 'interpersonal', 'decisional', and 'informational' functions by Mintzberg in 1973 (LEITE, 2009); not to mention the classic article by Robert L. Katz (1955), published by the Harvard Business Review, where the author proposed a subdivision of the skills needed by the administrator: (1) technical skill (specialised knowledge or mastery of tools and techniques used during typical activities performed personally; these skills may be acquired by experience, education, and professional training); (2) human skill (ability to work in a team and to promote cooperation); and (3) conceptual skill (ability to deal with complex relationships and to visualise the organisation as integrated and systemic, both internally and with the external environment (LOPES, FIALHO, LEONARDI et al., 2010).

Katz (1955) suggested that these three skills coexist within a manager's performance; the higher the administrative level, the more conceptual skills are required; on the other hand, the lower the hierarchical level, the more technical skills are required. The intermediary level requires nearly the same amount of technical, human, and conceptual skills, as seen in Figure 1.

Figure 1

Skills needed by the administrator proposed by KATZ (1955)

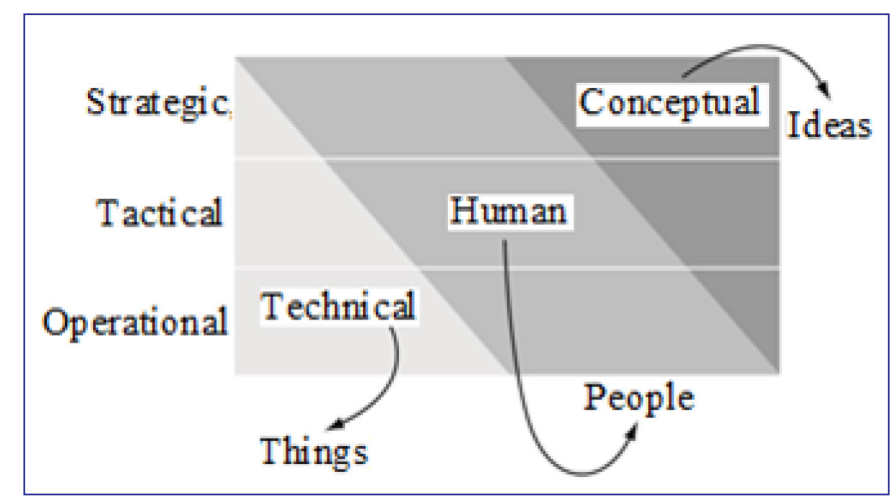

Source: Lopes, Fialho, Leonardi et al. (2010, p. 127). 
Contributions made by the organisational theories for the study of $M C$ that were idealised by Quinn, Thompson, Faermais et al. (2003) should also be highlighted. Box 3 summarises these aspects.

\section{Box 3}

Theoretical contributions for the study of MC and the main activities of managers

\begin{tabular}{|l|l|l|}
\hline \multicolumn{1}{|c|}{ Theory } & \multicolumn{1}{|c|}{ Main contribution } & \multicolumn{1}{c|}{ Main activities of managers } \\
\hline $\begin{array}{l}\text { Scientific Management } \\
\text { Theory (Taylor) }\end{array}$ & $\begin{array}{l}\text { Rationalisation of work and } \\
\text { efficiency }\end{array}$ & $\begin{array}{l}\text { Systematic selection of workers; worker adequacy for tasks; training; } \\
\text { incentives composition and offer; support workers, especially when planning } \\
\text { the best way to perform a task. }\end{array}$ \\
\hline Classical Theory (Fayol) & $\begin{array}{l}\text { Integration of people and } \\
\text { units, since it promoted } \\
\text { extreme specialisation }\end{array}$ & $\begin{array}{l}\text { Give orders; apply fair sanctions; elaborate plans to be performed by the } \\
\text { subordinates; provide a fair salary; promote order and harmony between } \\
\text { people and units. }\end{array}$ \\
\hline $\begin{array}{l}\text { Human Relations } \\
\text { Theory (Mayo) }\end{array}$ & $\begin{array}{l}\text { Consideration of the influence } \\
\text { of informality }\end{array}$ & $\begin{array}{l}\text { Mentor; empathetic attitude; promote teamwork; conflict management; } \\
\text { attention to motivational factors; facilitate the development of employees. }\end{array}$ \\
\hline $\begin{array}{l}\text { Bureaucratic Theory } \\
\text { Weber) }\end{array}$ & $\begin{array}{l}\text { Valorisation of internal } \\
\text { processes and division of } \\
\text { labour }\end{array}$ & $\begin{array}{l}\text { Clearly define workers' responsibilities; select workers objectively based on } \\
\text { merit and technical mastery; decide objectively, justify the arguments in } \\
\text { writing; standardise tasks, assembling them in manuals. }\end{array}$ \\
\hline $\begin{array}{l}\text { Contingency and } \\
\text { Systems Theories }\end{array}$ & $\begin{array}{l}\text { Consideration of } \\
\text { environmental unpredictability } \\
\text { and organisational flexibility }\end{array}$ & $\begin{array}{l}\text { Decide quickly; negotiate with political craftiness; innovate continuously; act } \\
\text { creatively; manage changes and risks. }\end{array}$ \\
\hline
\end{tabular}

Source: Elaborated by the authors based on Quinn, Thompson, Faermais et al. (2003).

Besides these theories, the resource dependency and institutional theories have also had important roles in the study of MC. The resource dependence theory has served a role because it assigns to managers the role of managing environmental conjectures by attracting resources required to achieve the results expected by the organisation from the treatment of environmental obstacles and interdependencies in order to optimise the resource domain (ALDRICH and PFEFFER, 1976; PFEFFER and SALANCIK, 2003). This theory also entrusts managers with the selection of strategic choices in order to manage and even manipulate organisational dependencies (THOMPSON, 1967). On the other hand, theorists from the institutional approach believe that $\mathrm{MC}$ focuses on the internalisation of regulations and other norms imposed by the organisational environment (MEYER and ROWAN, 1977; DIMAGGIO and POWELL, 1983). Based on legitimated rules and strategies, managers believe they shape their organisations in accordance with attitudes previously validated by model organisations, reaffirming practices already institutionalised (DIMAGGIO and POWELL, 1983).

Now that definitions and historical evolutions of the competencies phenomenon have been presented, as well as the main aspects regarding $M C$ - especially its relationship with organisational theories - it is time to present the method of this study.

\section{METHOD}

This is a bibliographic study with a posteriori classification of content analysis. The parametrisation of the bibliographic research prioritised articles published between 2005 and 2015 available at journal web portals such as CAPES, Scielo, ProQuest, Web of Science, and Google Scholar, containing expressions such as skill, competence, competences, competencies, managerial skill, managerial skills, managerial competence, managerial competences, and managerial competencies in the title, abstract, or keywords.

Forty-six articles were chosen, listing MC at several loci of research from small businesses to multinationals, with diverse objectives using quantitative and qualitative approaches. During the bibliographical study, the references were selected according to the adequacy and thematic relevance concerning the subject of study, considering studies containing empirical findings and those that presented some procedure of mapping or classification of MC in certain contexts appropriate, allowing 
the identification or classification of important competencies for managers. Moreover, attention was given to common and seminal references cited in the articles, so that studies before the already cited period were also considered.

Since there was no common understanding regarding the classifications used by the authors, the content analysis with a posteriori classification was used, considering different aspects within the identified MC categories (BERELSON, 1984; BARDIN, 2011). To do so, first an overall reading of the articles was performed, followed by a selective reading of the segments that indicated potential classifications for MC. Lastly, using this analytical reading, it was possible to suggest a posteriori classification. The analyses were performed using an electronic sheet, and the results will be presented and discussed in the following sections.

\section{MANAGERIAL COMPETENCIES: MODELS AND CLASSIFICATIONS}

The selected studies briefly presented represent only those that meet the criteria of proposing any scheme, model, categorisation, classification, or simply the identification of MC in a given context. Initially, studies guided by the Quinn model (1988) will be presented, since 12 studies were based on this model; after that, the other classifications located in empirical studies will be presented.

\section{THE QUINN MODEL (1988) AND ITS EMPIRICAL APPLICATION}

The Quinn model (1988) is based on the main theories that deal with this phenomenon: classical theory (rational goal model); humanist theory (human relations model); bureaucratic theories (internal process model); and open systems theory (considers the systemic and contingency perspectives). Its integrated model is summarised in Figure 2, which shows how the author uses the term 'role' as a cluster of MC aligned with the level of flexibility or control (vertical axis) and the predominant focus, whether internal or external (horizontal axis).

Figure 2

\section{Competencies and roles of leaders within the competing values framework}

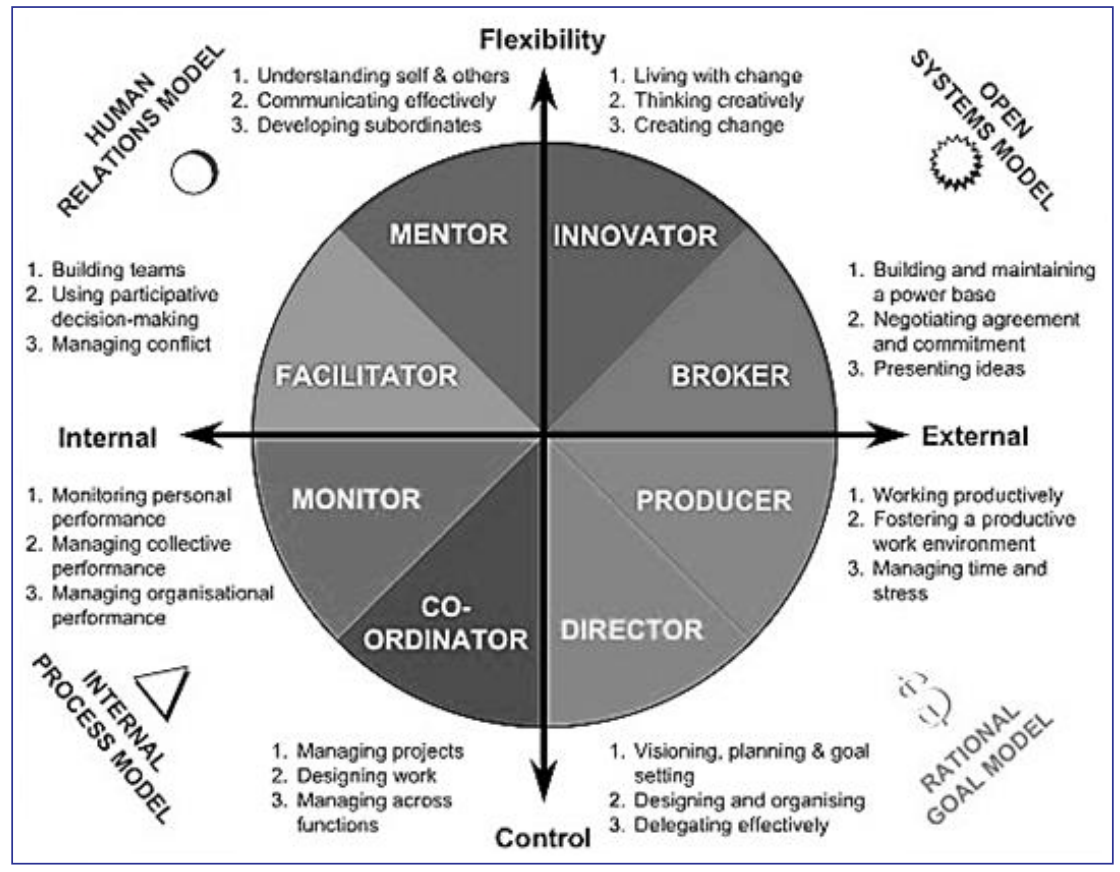

Source: Adapted from Quinn (1988, p. 48). 
In the role of the Producer, the manager is task-oriented and focused on work and high personal productivity, in order to increase production and achieve established goals. As a Director, the manager plans, set goals and targets, defines rules and policies, delimits problems, and selects alternatives. The role of Mentor guides the manager to devote himself to the development of people, providing training opportunities, praising and recognising people. The Facilitator has the role of fostering collective efforts and promotes joint solutions, teamwork, and manages interpersonal conflicts. In the role of Coordinator, the manager inspires confidence and credibility, and programs, organises and coordinates the team's efforts, crisis facing off and difficulties solving. As a Monitor, the manager monitors the progress of the unit which he is responsible for, analyses facts and its details, and verifies whether people are fulfilling the rules established. The role of Innovator is oriented towards adaptation and change, identifying trends and tolerating uncertainties and risks. To do so, favours creativity and innovation, presenting ideas in an inviting way. Finally, in the role of Negotiator, the manager is skilled in persuading and obtaining resources, has political cunning and influence, representing the unit or the organisation externally (QUINN, THOMPSON, FAERMAIS et al., 2003).

Once the main elements constituting Quinn's Model (1988) are known, its prominent to highlight the empirical findings of the 12 studies which, although using the Quinn Categorization (1988), have presented distinct goals, samples, loci and methodologies; which reflected in the prevalence of different roles, dependent on the type of organisation being surveyed or the functional area of the manager, as well as the identification of differences between MC formally established by the organisations and those actually required and the perception of managers and other professionals with which the managers work on.

As for the method, most of the studies applied mixed methods, combining questionnaires and qualitative methods, such as interviews (PICCHIAI, 2008), documentary surveys and direct observation (DIAS and PAIVA, 2009). However, there were also articles that exclusively used quantitative techniques, based on questionnaires or exclusively qualitative questionnaires, including documentary surveys and structured interviews (DIAS and PAIVA, 2011; PAIVA and FERREIRA, 2013), bibliographical survey and field research (BARROS, SILVA, LIMA et al., 2013), and semi-structured interviews (SEABRA, PAIVA and LUZ, 2015).

Regarding the application context, there were studies with managers and other professionals working in hospitals or health organisations (PICCHIAI, 2008; DIAS and PAIVA, 2011; NÓBREGA, GURGEL, BRITO et al., 2012); in banks (LEITE, 2009), in educational institutions (BARÁTH, 2007; DIAS and PAIVA, 2009; SEABRA, PAIVA and LUZ, 2015), in the textile industry (LOPES, FIALHO, LEONARDI et al., 2010), in the retail trade (PINTO, PEREIRA, SENNA et al., 2014), and in hotels (PAIVA, SANTOS and LACERDA, 2014), besides studies on MC of executive secretaries (BARROS, SILVA, LIMA et al., 2013) and managers in the area of information technology (PAIVA and FERREIRA, 2013).

As for the roles idealised by Quinn (1988), the results of the studies presented the following findings:

- The roles of Producer and Director were jointly identified as those of greatest dominance by nurses, nutritionists, and leaders in the area of information technology (IT) and perceived as the most prevalent in the managers of the educational system, according to the perspective of teachers. In the study of Picchiai (2008), these roles were perceived as a lesser degree of dominance. In an isolated analysis of these roles, the role of Director was only sensitive to the impact of the completion of certain managerial disciplines in the nursing course, besides being considered as a broad applicability to nursing graduation course coordinators, while the role of Producer was received in the hotel sector.

- The roles of Facilitator and Mentor were the most prominent in the studies and also of greater dominance in most studies, except in the case of nutritionists-managers, who indicated a greater deficit.

- The Coordinator and Monitor roles were jointly indicated as perceived at a lesser degree for management positions in a hospital (PICCHIAI, 2008) and more demanded by nurses (DIAS and PAIVA, 2011). In an isolated way, it is worth noting that IT leaders indicated that they have the least dominance in the role of Monitor.

- The Innovator and Broker roles in general were the ones with less prominence in the research results, being highlighted only by Picchiai (2008) as probably required because the hospital is highly influenced by the external environment, especially in the social, technical, and cultural interference of the university and the health system. Baráth (2007) indicated that, according to the managers, these are the most prevalent roles of their performance, together with the roles of Facilitator and Mentor. Paiva, Santos and Lacerda (2014) reported that they considered these roles requirements of the hotel sector. 
In regards the objectives, it is possible to conclude that studies that reached for the Quinn model (1988) seem to pursue at least one of the four essential purposes, namely: (1) identifying domains or gaps of $\mathrm{MC}$ in managers or other professionals whose functions require management activities; (2) verifying compatibility between the MC presented and those in fact necessary to the context, or even those required by authorities or higher ranking executives (real $x$ desired); (3) comparing the mastery of $\mathrm{MC}$ before and after a given management training; and (4) the development of a standard questionnaire able to identify the mastery of $\mathrm{MC}$ regardless of the studied context.

Concerning the last purpose (the fourth one), it is considered a mistake to disregard the context as a constitutive element of the competence definition. Although it is known that some $\mathrm{MC}$ may be generic or transversal, the adequacy of the researched context is fundamental, since it strongly interferes in writing and clarity of items on a scale.

Another highlight is that the Quinn (1988) model refers to roles as sets or clusters of similar MC. However, this is not the only way to understand it. For example, a competent negotiator may exercise this competence when performing his various roles in society: as a father, boss, son, student, consumer, friend, and others. In other words, the logic may be reversed: a competence may be exercised in multiple roles (KONRATH, TAROUCO and BEHAR, 2009; LITTO and FORMIGA, 2009). At this point, there is no right or wrong, but it is important to highlight that there are different ways to see the role-competence relation.

To sum up, the Quinn model (1988) is considered robust for the classification of MC and owns a validated scale developed by Denison, Hooijberg and Quinn (1995) and applied by several researchers such as Vilkinas (2000), Paiva and Ferreira (2013) and Paiva, Santos and Lacerda (2014). However, there are other studies regarding MC that present classifications, which will be studied in the following section.

\section{OTHER CLASSIFICATIONS OF MANAGERIAL COMPETENCIES IN SEVERAL EMPIRICAL STUDIES}

The studies selected in the bibliographic research that did not recur to the Quinn model (1988) totalled 34 articles: Félix (2005); Moura and Bitencourt (2006); Godoy and Forte (2007); Santos, Caetano and Jesuíno (2008); Moraes and Corrêa (2008); Jansen, Vera and Crossan (2009); Cardoso (2009); Brandão, Borges-Andrade, Freitas et al. (2010); Noro and Abbade (2010); Teixeira, Silva and Lima (2011); Ésther (2011); Pelissari, Gonzalez and Vanelle (2011); Fleck and Pereira (2011); Mithas, Ramasubbu and Sambamurthy (2011); Bündchen, Rossetto and Silva (2011); Brandão, Borges-Andrade and Guimarães (2012); Godoy and D'amelio (2012); Baisch, Estrada, Scherer et al. (2012); Galvão, Silva and Silva (2012); Brito and Leone (2012); Brito, Paiva and Leone (2012); Sousa and Valadão Júnior (2013); Paula, Peres, Bernardino et al. (2013); Ferigotti and Fernandes (2014); Almeida and Muniz Júnior (2014); Cardoso (2014); Irmão and Barbalho (2014); Mello and Melo (2014); Regio, Schuch, Gomes et al. (2014); Santos and Honório (2014); Silva, Gil and Okabayashi (2014); Tosta and Dalmau (2014); Nascimento and Alves (2015) and Peixoto and Souza (2015).

These articles presented several classifications for $\mathrm{MC}$ and were applied to multiple contexts, all regarding public services (public universities and schools, prison institutions, city halls, military organisations, power companies, public banks) and private initiatives (laboratories, information technology companies, home appliance industry, textile companies, marketing companies, and so on).

The content analysis regarding classifications of $M C$ in those studies was based on nomenclature and terms used in the same studies, grouping $\mathrm{MC}$ according to their subject, considering constitutive and/or operational definitions presented by the authors. Consequently, it was possible to identify 19 categories defined a posteriori, presented in Box 4, along with some expressions or excerpts that enabled the identification of the category. 


\section{Box 4}

\section{Categories of $\mathrm{MC}$ and their respective expressions}

\begin{tabular}{|c|c|}
\hline Category & Excerpts and expressions identified during content analysis \\
\hline $\begin{array}{l}\text { Results orientation } \\
\text { (found in } 26 \text { studies) }\end{array}$ & $\begin{array}{l}\text { Results-oriented management; focus on product, client, business, results; economic result; market, costs, results } \\
\text { orientation; goal achievement; financial business management. }\end{array}$ \\
\hline $\begin{array}{l}\text { Ability with people and } \\
\text { teams (found in } 24 \\
\text { studies) }\end{array}$ & $\begin{array}{l}\text { Manage relations; bring people together; demonstrate interest in people; be receptive; teamwork; collaboration; } \\
\text { cooperation; social competence; deal with diverse cultures; monitor individual's and team's development; } \\
\text { prepare substitutes; know the potential and deficiency of the team; facilitate learning; personal development } \\
\text { and permanent education. }\end{array}$ \\
\hline $\begin{array}{l}\text { Leadership, } \\
\text { coordination, and } \\
\text { motivation (found in } \\
19 \text { studies) }\end{array}$ & $\begin{array}{l}\text { Leadership, coordination; direction; lead efforts to a common purpose; incentive for passion; determination and } \\
\text { motivation; firmness of purpose; ability to motivate and engage the team; acknowledge, stimulate and reward } \\
\text { people; coordinate actions. }\end{array}$ \\
\hline $\begin{array}{l}\text { Ability with change } \\
\text { (found in } 18 \text { studies) }\end{array}$ & $\begin{array}{l}\text { Innovation; situational adaptation; keep the team updated about events and changes; stimulate risk taking } \\
\text { and creativity; risk taking; stimulate incremental adaptation and improvement; situational leadership; change } \\
\text { management; participate in change; perception of change; flexibility; ability to technologically innovate; openness } \\
\text { to adapt to change; mobilisation for change; plan and execute change; search for original solutions }\end{array}$ \\
\hline $\begin{array}{l}\text { Communication (found } \\
\text { in } 17 \text { studies) }\end{array}$ & $\begin{array}{l}\text { Know how to listen to, give, and receive feedback with confidence; know the target audience; dialogue; } \\
\text { communicate responsibilities; consistency between talking and acting; communicate clearly and objectively; } \\
\text { transmit necessary instructions. }\end{array}$ \\
\hline $\begin{array}{l}\text { Planning (found in } 16 \\
\text { studies) }\end{array}$ & $\begin{array}{l}\text { Plan; perform studies and research; time management; discern priorities; strategic planning; time scaling; } \\
\text { formulate action plans; sense of priority. }\end{array}$ \\
\hline $\begin{array}{l}\text { Knowledge } \\
\text { management (found in } \\
15 \text { studies) }\end{array}$ & $\begin{array}{l}\text { Create and share knowledge; search, register, evaluate, and disseminate information; monitor documents, } \\
\text { records, and processes; manage information systems and services; formulate and manage information projects; } \\
\text { establish traceability mechanisms. }\end{array}$ \\
\hline $\begin{array}{l}\text { Organisation and } \\
\text { control (found in } 15 \\
\text { studies) }\end{array}$ & $\begin{array}{l}\text { Integrate several departments. Organise, keep the team updated on routines; manage internal processes; deal } \\
\text { with available material and human resources; process management; resource management; resource allocation; } \\
\text { use rationally the available resources; control; create control mechanisms; discipline the team; periodic monitoring } \\
\text { of the team's development; verify procedures fulfilment; demand excellence and accuracy; establish control } \\
\text { mechanisms. }\end{array}$ \\
\hline $\begin{array}{l}\text { Strategic vision (found } \\
\quad \text { in } 14 \text { studies) }\end{array}$ & $\begin{array}{l}\text { Strategic management; strategic skills; future vision; ability to interrelate external reality and business; ability } \\
\text { to understand concepts and transfer them to the business reality; understand the business and its objectives } \\
\text { when dealing with the market; foresee threats and opportunities; strategic vision; strategic thinking; define } \\
\text { goals and objectives. }\end{array}$ \\
\hline $\begin{array}{l}\text { Negotiation (found in } \\
13 \text { studies) }\end{array}$ & $\begin{array}{l}\text { Negotiation; persuasion; negotiation techniques; present new ideas; negotiation assertiveness; public relations } \\
\text { techniques; know verbal expression and oratory techniques. }\end{array}$ \\
\hline $\begin{array}{l}\text { Ability with conflicts } \\
\text { (found in } 12 \text { studies) }\end{array}$ & Conflict management; deal with conflicts; manage conflicts; manage conflicting relations; conflict manager. \\
\hline $\begin{array}{c}\text { Decision-making } \\
\text { (found in } 12 \text { studies) }\end{array}$ & decision from the analysis of several aspects. \\
\hline
\end{tabular}




\begin{tabular}{|c|c|}
\hline Category & Excerpts and expressions identified during content analysis \\
\hline $\begin{array}{l}\text { Ability to deal with } \\
\text { problems and } \\
\text { opportunities (found in } \\
8 \text { studies) }\end{array}$ & $\begin{array}{l}\text { Recognise problems and opportunities; problem solving; attract opportunities; ability to identify and solve } \\
\text { problems; problem 'solver'; apply technical knowledge to solve problems. }\end{array}$ \\
\hline $\begin{array}{l}\text { Critical, logical, and } \\
\text { analysis/synthesis } \\
\text { abilities (found in } \\
8 \text { studies) }\end{array}$ & $\begin{array}{l}\text { Critical and analytical thinking; ability to correlate facts with impacts in the organisation; analyse results; think } \\
\text { in a logical and analytical way; stablish formal and causal relations between the phenomena. }\end{array}$ \\
\hline $\begin{array}{l}\text { Empowerment, } \\
\text { delegation, and } \\
\text { deconcentration } \\
\text { (found in } 7 \text { studies) }\end{array}$ & $\begin{array}{l}\text { Shared management; decentralized management; participative decision-making; elucidate roles; ability to delegate; } \\
\text { delegate with responsibility; assign tasks to employees; distribute tasks and responsibilities; willingness to delegate. }\end{array}$ \\
\hline $\begin{array}{l}\text { Systemic vision (found } \\
\text { in } 7 \text { studies) }\end{array}$ & $\begin{array}{l}\text { Intersectoral management; systemic vision, business vision in its entirety; ability to integrate the different } \\
\text { departments of the organisation to contribute for the business as a whole; global competencies. }\end{array}$ \\
\hline $\begin{array}{l}\text { Political and network } \\
\text { articulation abilities } \\
\text { (found in } 5 \text { studies) }\end{array}$ & $\begin{array}{l}\text { Stimulate the establishment of network structures; political abilities (representation); articulation; how to deal } \\
\text { with clients and competitors; deal with political and social environment; relationship with the client; relationship } \\
\text { with partners and suppliers; articulate partnerships. }\end{array}$ \\
\hline $\begin{array}{l}\text { Attitudes and values } \\
\text { (found in } 16 \text { studies) }\end{array}$ & $\begin{array}{l}\text { Tolerance; initiative; perception and intuition; ethical posture; boldness; patience; weighting; reliability; adequacy; } \\
\text { socio-environmental responsibility; proactivity; work under pressure; sense of responsibility; self-control; dynamism; } \\
\text { respect others; honesty; justice; agility; entrepreneurship; engagement, calmness; resiliency; politeness. }\end{array}$ \\
\hline $\begin{array}{l}\text { Knowledge, skills, and } \\
\text { techniques (found in } \\
15 \text { studies) }\end{array}$ & $\begin{array}{l}\text { Technical professional competency; technical skills; knowledge of the system; technical skills; knowledge of } \\
\text { the institution; notorious specialisation in the field; technical mastery of the processes; and search for specific } \\
\text { technical knowledge. }\end{array}$ \\
\hline
\end{tabular}

Source: Elaborated by the authors based on content analysis with a posteriori classification.

Overall, the MC categories identified in this study are compatible with the most traditional classifications of MC that address aspects regarding relations, goals, and changes. It is also possible to say that almost all categories are analogous to Quinn's categorisation (1988). However, the last two categories need additional comments. As of the 'attitudes and values' category, it is worth highlighting that many studies demonstrated to be inaccurate when distinguishing organisational values and attitudinal components of competencies. It may bring some issues, since attitudes integrate the traditional definition of MC, but organisational values do not. Indeed, human values interfere and compose the attitudes and behaviours of individuals (SCHWARTZ and BILSKY, 1990), but organisational values guide the desirable human behaviour in an extrinsic way in order to subordinate individual interests to collective ones in achieving shared goals (OLIVEIRA and TAMAYO, 2004; TAMAYO, 2008). In any case, it is necessary to report that it seems to have a tendency that models and classifications of MC are increasingly incorporating organisational values as something that guides attitudes, and because of that, they start to consider them in MC charts. In other words, when thinking about the necessary elements of a competent professional performance, values should be considered as well (CHEETHAM and CHIVERS, 2005).

With regard to the 'technical competencies and abilities' category, it is worth emphasising that its presence in the MC listing should be questioned, since technical competencies are related to operating and specific and advisory activities - and in principle, they are not related to managers. It is possible that this inclusion of technical competencies in the MC listing is due to the fact that many managers reached the managerial position as a result of a superior performance in technical competencies, especially because managerial activities demand a minimum number of technical competencies in the field, 
which is presented in Katz's model (1955), aforementioned in the theoretical framework. Nonetheless, it is believed that the phenomena should be treated in different ways. In other words, even considering the relevant role of technical competencies for the managerial performance, MC models should address them separately, since - despite specificities of the context MC are transversal by nature (ÇIZEL, ANAFARTA and SARVAN, 2007), and technical competencies are characterised by being related to some professions, functional areas, and business fields.

Concluding the exposition of the selected works about MC, it is important to mention that in spite of Brandão's (2007) criticism concerning studies that conceptualise competencies using the element of 'synergistic combination of knowledge, skills, and attitudes - KSA' and perform mappings of competencies in a segregated manner, some studies selected in this theoretical framework still diagnose competencies reaching out to KSAs separately. It would be better if the instruments and models about competencies conjugated KSAs into 'behaviours' - an approach that is suggested as more suitable than an aggregatorsynergistic element to the parts of KSA.

\section{FINAL CONSIDERATIONS}

This study reviewed empirical research from the last decade, aiming to identify the most cited models of MC. The Quinn model (1988) was the most used during this period although it was created almost three decades ago. Its use and solidity are probably because of the range (aggregating MC privileged by theories associated to rational goals, human relations, internal processes, and systemic situational perspective) and because it includes relations experienced by managers, depending on the emphasis on the environment (internal or external) and characteristics of the context and managers' profiles (flexibility or control).

Furthermore, based on Box 4 and with the exception of the studies based on the Quinn model (1988), the content analysis showed that the $10 \mathrm{MCs}$ with a higher incidence in studies of the last decade (2005 to 2015) are: results orientation (clients, processes, costs, market, products, projects, etc.); people and team skills (interpersonal relationship, cooperation, etc.); leadership, coordination, and motivation; ability with change (innovation and situational adaptability skills); communication; planning; attitudes and values (ethics, initiative, commitment, etc.); knowledge management; knowledge and technical skills; and organisation and control (resource allocation, mobilisation, and monitoring).

The aforementioned MCs are not necessarily the most important or essential. However, it is considered that this study brings contributions to the field once the identification of the most cited MCs becomes a previous step to the identification of the most relevant MCs; and with this being so, a recommendation is made for future studies.

Therefore, even considering the competencies as context-dependant, it is suggested that a study be developed that is capable of presenting empirical evidence of the basic, general, transversal, or common MCs, regardless of the locus of research. It is necessary to proceed with the identification of critical contextual factors and which of these factors can be considered less rigorously. This identification may simplify or guide the diagnosis of $M C$, encouraging future studies to focus on mapping specific and peculiar behaviours of the studied locus of research. Unfortunately, a good amount of the studies that attempt to propose a generic model of MC neglect these aspects, ignoring the contribution of the French school of competencies, whose basic assumption is to consider the context as a central element of competencies.

Besides redressing this challenge, future research agenda must also include studies that correlate MC with the period of experience of managers, since it is believed that the learning that transcends maturation may provide a greater range of repertoires in the performance of managers, better support for decision-making, and greater flexibility when facing diverse contexts (ABBAD and BORGES-ANDRADE, 2004).

It is worth noting as a study limitation that, although having presented classifications from over 11 years (2005 to 2015), the research presented only reveals the static feature of $M C$ during the studied period, since the research design adopted a crosscutting approach and is limited on time (JUNG, 2011). Thus, the replication of this study would be relevant, especially to verify the dynamic of MC throughout future years.

Ultimately, considering these limitations, recommendations, and suggestions for future research, it is expected that this identification of a model as well as the most cited MCs in that period assist organisations with successfully fulfilling their purpose, and consequently, delivering better results to society. 


\section{REFERENCES}

ABBAD, G.; BORGES-ANDRADE, J. Aprendizagem humana nas organizações e trabalho. In: ZANELLI, J. C.; BORGES-ANDRADE, J. E.; BASTOS, A. V. B. (Org.). Psicologia, organizações e trabalho no Brasil. Porto Alegre: Artmed, 2004. p. 237-275.

ALDRICH, H.; PFEFFER, J. Environments of organizations. Annual review of sociology, v. 2, p. 79-105, 1976.

ALMEIDA, J.; MUNIZ, J. Comportamentos gerenciais para implantação da norma de qualidade-uma análise para certificação Vda 6.3. In: SIMPÓSIO DE EXCELÊNCIA EM GESTÃO E TECNOLOGIA, 9, 2014. Anais... Resende, RJ, 2014.

ANTONELLO, C. Articulação da aprendizagem formal e informal: seu impacto no desenvolvimento de competências gerenciais. Revista Alcance, v. 12, n. 2, p. 183-209, 2005.

BAISCH, L. et al. Gestão estratégica e as competências gerenciais no departamento de marketing: estudo de uma indústria de bebidas. Revista de Administração da UFSM, v. 5, n. esp., p. 729-748, 2012.

BARÁTH, T. Effectiveness in public education: Models and aspects of leadership. In: ENIRDEM CONFERENCE, 2007. Proceedings... Budapest, 2007. Available at: <http://ofi.hu/effectiveness-public-educationmodels-and-aspects-leadership>. Accessed on: 12 Dec. 2015.

BARDIN, L. Análise de conteúdo. São Paulo: Edições 70, 2011.

BARROS, C. et al. As competências gerenciais desenvolvidas pelos secretários executivos. Revista de Gestão e Secretariado, v. 4, n. 2, p. 25-47, 2013.

BERELSON, B. Content analysis in communication research. New York: Hafner, 1984.

BERGENHENEGOUWEN, G.; HORN, H.; MOOIJMAN, E. Competence development - a challenge for human resource professionals: core competences of organizations as guidelines for the development of employees. Industrial and commercial training, v. 29, n. 2, p. 55-62, 1997.

BRANDÃO, H. Competências no trabalho: uma análise da produção científica brasileira. Estudos de Psicologia, v. 12, n. 2, p. 149-158, 2007.

BRANDÃO, $\mathrm{H}$. et al. Desenvolvimento e estrutura interna de uma escala de competências gerenciais. Psicologia: Teoria e Pesquisa, v. 26, n. 1, p. 171-182, 2010.

BRANDÃO, H.; BORGES-ANDRADE, J.; GUIMARÃES, T. Desempenho organizacional e suas relações com competências gerenciais, suporte organizacional e treinamento. R. Adm., São Paulo, v. 47, n. 4, p. 523539, Oct./Dec. 2012.

BRANDÃO, H.; BORGES-ANDRADE, J. Causas e efeitos da expressão de competências no trabalho: para entender melhor a noção de competência. Revista de Administração Mackenzie, v. 8, n. 3, p. 32-49, 2008.

BRITO, L.; LEONE, M. Competências gerenciais requeridas em empresas familiares: um olhar feminino. Revista de Ciências da Administração, v. 14, n. 32, p. 50-64, 2012.

BRITO, L.; PAIVA, L.; LEONE, N. Perfil de competências gerenciais no Ensino Superior Tecnológico. Revista Ciências Administrativas, v. 18, n. 1, p. 189-216, Jan./Jun. 2012.
BÜNDCHEN, E.; ROSSETTO, C.; SILVA, A. Competências Gerenciais em Ação - O Caso do Banco do Brasil. Revista Eletrônica de Administração, v. 17, n. 2, p. 396-423, 2011.

CARBONE, P. P.; BRANDÃO, H. P.; LEITE, J. B. D. Gestão por competências e gestão do conhecimento. Rio de Janeiro: FGV, 2009.

CARDOSO, A. Percepções de gestores sobre competências gerenciais em diferentes contextos: estabilidade e mudança organizacional. REBRAE. Revista Brasileira de Estratégia, v. 2, n. 2, p. 147-169, May/Aug., 2009.

CARDOSO, A. Questão de Gênero: A Percepção de Alunos d Ex-Alunos de Pós-Graduação Stricto Sensu em Administração sobre Competências Gerenciais. Revista de Carreiras e Pessoas (ReCaPe), v. 4, n. 1, p. 18-34, 2014.

ÇIZEL, B.; ANAFARTA, N.; SARVAN, F. An analysis of managerial competency needs in the tourism sector: the case of Turkey. Tourism Review, v. 62, n. 2, p. 14-22, 2007.

DENISON, D.; HOOIJBERG, R.; QUINN, R. Paradox and performance: Toward a theory of behavioral complexity in managerial leadership. Organization Science, v. 6, n. 5, p. 524-540, 1995.

DIAS, H.; PAIVA, K. Formação de competências gerenciais a partir de disciplinas de gestão no curso de enfermagem: percepções de alunos de uma universidade privada. Revista Mineira de Enfermagem, v. 13, n. 4, p. 474-484, 2009.

DIAS, H.; PAIVA, K. Competências do enfermeiro: estudo em um hospital privado. Rev. bras. enferm, v. 64, n. 3, p. 511-520, 2011.

DIMAGGIO, P.; POWELL, W. The iron cage revisited: Collective rationality and institutional isomorphism in organizational fields. American Sociological Review, v. 48, n. 2, p. 147-160, 1983.

DUTRA, J. Competências: conceitos e instrumentos para a gestão de pessoas na empresa moderna. São Paulo: Atlas, 2004.

ÉSTHER, A. As competências gerenciais dos reitores de universidades federais em Minas Gerais: a visão da alta administração. Cadernos EBAPE. BR., v. 9, n. esp., p. 648-667, 2011.

FÉLIX, C. A prática de competências gerenciais no setor público. Revista de Administração Pública, v. 39, n. 2, p. 255-278, 2005.

FERIGOTTI, C.; FERNANDES, B. Competências Gerenciais E Capacidade Para Inovação: O Caso da Electrolux Do Brasil S/A. RAI: revista de administração e inovação, v. 11, n. 1, p. 73-96, 2014.

FLECK, C.; PEREIRA, B. Professores e Gestores: análise do perfil das Competências Gerenciais dos coordenadores de pós-graduação das Instituições Federais de Ensino Superior (IFES) do RS. Organizações \& Sociedade, v. 18, n. 57, p. 285-301, 2011.

FLEURY, M.; FLEURY, A. Construindo o conceito de competência. Revista de administração contemporânea, v. 5, n. esp., p. 183-196, 2001.

GALVÃO, V.; SILVA, A.; SILVA, W. O desenvolvimento de competências gerenciais nas escolas públicas estaduais. Educação e Pesquisa, v. 38, n. 1, p. 131-147, 2012.

GARAVAN, T.; MCGUIRE, D. Competencies and workplace learning: some reflections on the rhetoric and the reality. Journal of Workplace learning, v. 13, n. 4, p. 144-164, 2001. 
GODOY, A.; ANTONELLO, C. Competências individuais adquiridas durante os anos de graduação de alunos do Curso de Administração de Empresas. Revista de Ciências da Administração, v. 11, n. 23, p. 157-191, 2009.

GODOY, A.; D'AMELIO, M. Competências gerenciais desenvolvidas por profissionais de diferentes formações. Organizações \& Sociedade, v. 19, n. 63, p. 621-639, 2012.

GODOY, A.; FORTE, D. Competências adquiridas durante os anos de graduação: um estudo de caso a partir das opiniões de alunos formandos de um curso de administração de empresas. Gestão \& Regionalidade, v. 23, n. 68, p. 56-69, 2007.

GONCZI, A. Competency-based learning: a dubious past-an assured future?. In: BOUD, D.; GARRICK, J. (Ed.). Understanding learning at work. Londres: Routledge, 1999. p. 180-194.

GUIMARÃES, T. A. et al. Forecasting core competencies in an R\&D environment. R and D Management, v. 31, n. 3, p. 249-255, 2001.

IRMÃO, M.; BARBALHO, C. Competências gerenciais dos gestores de bibliotecas universitárias de instituições de ensino público em Manaus. Biblionline, v. 10, n. 2, p. 97-107, 2014.

JANSEN, J.; VERA, D.; CROSSAN, M. Strategic leadership for exploration and exploitation: The moderating role of environmental dynamism. The Leadership Quarterly, v. 20, n. 1, p. 5-18, 2009.

JUNG, C. Metodologia Científica: Ênfase em Pesquisa Tecnológica. 3. ed. rev. e aum., 2003. Available at: <http://www.mecanica.ufrgs.br/ promec/alunos/download/metodolo.pdf>. Accessed on: 11 Feb. 2015.

KATZ, R. Skills of an effective administrator. Harvard Business, p. 33-42, 1955.

KONRATH, M.; TAROUCO, L.; BEHAR, P. Competências: desafios para alunos, tutores e professores da EaD. RENOTE, v. 7, n. 1, 2009.

LEITE, M. Desenvolvimento de competências gerenciais e aprendizagem experiencial: um estudo entre os gerentes de agência do Banco do Brasil no Estado do Ceará. In: ENCONTRO ANUAL DA ASSOCIAÇÃO NACIONAL DE PÓS-GRADUAÇÃO E PESQUISA EM ADMINISTRAÇÃO, 33, 2009. Anais...São Paulo: EnANPAD, 2009.

LIMA, V. Competência: distintas abordagens e implicações na formação de profissionais de saúde. Interface Comun Saúde Educ, v. 9, n. 17, p. 369-79, 2005.

LITTO, F.; FORMIGA, M. Educação a Distância: Estado da Arte. São Paulo: Pearson Education do Brasil, 2009.

LOPES, M. et al. Análise da relação entre aptidões cerebrais e competências gerenciais: o caso de uma empresa têxtil. Gest. Prod., São Carlos, v. 17, n. 1, p. 123-136, 2010.

MCMULLAN, M. et al. Portfolios and assessment of competence: a review of the literature. Journal of advanced nursing, v. 41, n. 3, p. 283-294, 2003.

MELLO, S.; MELO, P. Mapeando competências gerenciais dos integrantes do Fórum de Gestão de Pessoas da Rede Federal de Educação profissional, científica e tecnológica. In: CONGRESSO CONSAD DE GESTÃO PÚBLICA, 7, 2014. Anais...Brasília: CONSAD, 2014.

MEYER, J.; ROWAN, B. Institutionalized organizations: Formal structure as myth and ceremony. American journal of sociology, v. 83, n. 2, p. 340-363, 1977.
MITHAS, S.; RAMASUBBU, N.; SAMBAMURTHY, V. How Information Management Capability Influences Firm Performance. MIS quarterly, v. 35, n. 1, p. 237-256, 2011.

MONTEZANO L.; SILVA, D.; COELHO JR. F. Competências Humanas no Trabalho: a Evolução das Publicações Nacionais no Novo Milênio. In: ENCONTRO DA ASSOCIAÇÃO NACIONAL DE PÓS-GRADUAÇÃO E PESQUISA EM ADMINISTRAÇÃO, 39, 2015. Anais... Belo Horizonte: EnANPAD, 2015.

MORAES, M.; CORRÊA, M. Competência Comunicativa dos Líderes e os Resultados da Equipe. In: ENCONTRO DA ASSOCIAÇÃO NACIONAL DE PÓS-GRADUAÇÃO E PESQUISA EM ADMINISTRAÇÃO, 32, 2008. Anais... Rio de Janeiro: EnANPAD, 2008.

MOURA, M.; BITENCOURT, C. A articulação entre estratégia e o desenvolvimento de competências gerenciais. RAE-eletrônica, v. 5, n. 1, Jan./Jun. 2006.

NASCIMENTO, M.; ALVES, M. Competências do administrador: um estudo comparativo entre a percepção da academia e do mercado. In: SEGET - SIMPÓSIO DE EXCELÊNCIA DE GESTÃO E TECNOLOGIA, 7, 2015. Anais...Resende: SEGET, 2015.

NÓBREGA, A. et al. Competências Gerenciais do nutricionista gestor de unidades de alimentação terceirizada. RAUnP, v. 4, n. 2, p. 49-60, 2012.

NORO, G.; ABBADE, E. Os tipos de projetos e as competências gerenciais nos projetos da AES sul distribuidora gaúcha de energia SA. Revista Gestão Organizacional, v. 3, n. 2, p. 141-162, 2010.

ODELIUS, C. et al. Processos de aprendizagem, competências aprendidas, funcionamento, compartilhamento e armazenagem de conhecimentos em grupos de pesquisa. Cadernos EBAPE. BR, v. 9, n. 1, p. 199-220, 2011.

OLIVEIRA, A.; TAMAYO, A. Inventário de perfis de valores organizacionais. Revista de Administração, v. 39, n. 2, p. 129-140, 2004.

PAIVA, K.; FERREIRA, L. Competências Gerenciais na área de Tecnologia de Informação: um estudo com gestores de empresas localizadas no Triângulo Mineiro. Revista Gestão \& Tecnologia, v. 13, n. 1, p. 205-229, 2013.

PAIVA, K.; SANTOS, A.; LACERDA, M. Competências gerenciais e sua gestão na hotelaria: um estudo com gestores brasileiros. Tourism \& Management Studies, v. 10, n. 2, p. 84-93, 2014.

PARRY, S. The Quest for Competencies. Training, v. 33, n. 7, p. 48-54, 1996.

PAULA, M. et al. Processo de trabalho e competências gerenciais do enfermeiro da estratégia saúde da família. Revista da Rede de Enfermagem do Nordeste-Rev Rene, v. 14, n. 5, 967-973, 2013.

PEIXOTO, A.; SOUZA, J. Longe dos olhos, longe do coração: desafios de gestão de uma universidade pública a partir da percepção dos seus gestores. Revista Gestão Universitária na América Latina-GUAL, v. 8, n. 3, p. 240-260, 2015.

PELISSARI, A.; GONZALES, I.; VANALLE, R. Competências gerenciais: um estudo em pequenas empresas de confecções. Revista Eletrônica de Administração, v. 17, n. 1, p. 149-180, 2011.

PFEFFER, J.; SALANCIK, G. The external control of organizations: A resource dependence perspective. Stanford University Press, 2003. 
PICCHIAI, D. Competências gerenciais: estudo de caso de um hospital público. Cadernos Gestão Pública e Cidadania, v. 13, n. 52, p. 19-41, 2008.

PINTO, J. et al. Competências Gerenciais: Um Estudo Exploratório em uma Rede do Comércio Varejista. Global Manager, v. 14, n. 2, p. 23-40, 2014.

QUINN, R. et al. Competências gerenciais princípios e aplicações. Rio de Janeiro: Editora Campus, 2003.

QUINN, R. Beyond rational management: Mastering the paradoxes and competing demands of high performance. New Jersey: JosseyBass, 1988.

REGIO, M. et al. Gestão de competências profissionais na formação de administradores. Avaliação: Revista da Avaliação da Educação Superior, v. 19, n. 1, 129-153, 2014.

ROWE, C. Clarifying the use of competence and competency models in recruitment, assessment and staff development. Industrial and Commercial training, v. 27, n. 11, p. 12-17, 1995.

SANTOS, E.; HONÓRIO, L. Competências Gerenciais em uma Rede Mineira de Farmácias. Revista Alcance, v. 21, n. 4, p. 650-673, 2014.

SANTOS, J., CAETANO, A., JESUÍNO, J. As competências funcionais dos líderes e a eficácia das equipas. Revista Portuguesa e Brasileira de Gestão, p. 22-33, Jul./Sept. 2008.

SCHWARTZ, S.; BILSKY, W. Toward a theory of the universal content and structure of values: Extensions and cross-cultural replications. Journal of personality and social psychology, v. 58, n. 5, p. 878-891, 1990.

SEABRA, A.; PAIVA, K.; LUZ, T. Managerial competences of coordinators of undergraduate nursing courses. Revista Brasileira de Enfermagem, v. 68, n. 5, p. $890-898,2015$.
SILVA, E.; GIL, A.; OKABAYASHI, S. Competências na gestão pública: uma avaliação dos servidores públicos do Grande $A B C$ paulista. Gestão Pública: Práticas e Desafios, v. 5, n. 1, p. 88-106, 2014.

SOUSA, A.; VALADÃO JR., V. Competências gerenciais no contexto internacional: possíveis contribuições de cursos superiores brasileiros de Administração. Organizações \& Sociedade, v. 20, n. 66, p. 383402, 2013.

STUART, R.; LINDSAY, P. Beyond the frame of management competenc (i) es: towards a contextually embedded framework of managerial competence in organizations. Journal of European Industrial Training, v. 21 , n. 1, p. 26-33, 1997.

TAMAYO, A. Valores organizacionais e comprometimento afetivo. Revista de Administração Mackenzie, v. 6, n. 3, p. 192-213, 2008.

TEIXEIRA, L.; SILVA, J.; LIMA, H. Administração no sistema prisional - um estudo das competências gerenciais. Contextus-Revista Contemporânea de Economia e Gestão, v. 9, n. 2, p. 55-67, 2011.

THOMPSON, J. Organizations in action: Social science bases of administrative theory. New Jersey: Transaction publishers, 1967.

TOSTA, H.; DALMAU, M. Competências gerenciais requeridas aos gestores intermediários da Universidade Federal da Fronteira Sul. In: CONGRESSO CONSAD DE GESTÃO PÚBLICA, 7, 2014. Anais... Brasília: CONSAD, 2014

VILKINAS, T. The gender factor in management: how significant others perceive effectiveness. Women in Management Review, $\mathrm{v}$. 15, n. 5/6, p. 261-272, 2000.

ZAGORŠEK, H.; DIMOVSKI, V.; ŠKERLAVAJ, M. Transactional and transformational leadership impacts on organizational learning. Journal for East European Management Studies, v. 14, n. 2, p. 144-165, 2009.

Pablo Fernando Pessoa de Freitas

PhD student in Administration for the Department of Administration; Postgraduate Program in Administration, Faculty of Economics, Administration and Accounting. Universidade de Brasília (UnB), Brasília - DF, Brazil. E-mail: freitaspfp@gmail.com

Catarina Cecília Odelius

PhD in Psychology from the Department of Social and Work Psychology, Universidade de Brasília (UnB); Collaborator researcher at the Graduate Program of Administration; Universidade de Brasília (UnB), Brasília-DF, Brazil. E-mail: codelius@unb.br 